\title{
Evaluation of right ventricular function in operated tetralogy of Fallot patients with tissue Doppler imaging before and after pulmonary valve replacement
}

\author{
Ameliyat edilmiş Fallot tetralojili hastalarda pulmoner kapak replasmanı öncesi ve sonrası \\ sağ ventrikül fonksiyonlarının doku Doppler görüntüleme ile değerlendirilmesi

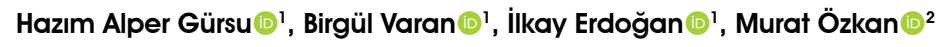 \\ 'Department of Pediatric Health and Diseases, Division of Pediatric Cardiology, Medicine Faculty of Başkent University, Ankara, Turkey \\ ${ }^{2}$ Department of Cardiovascular Surgery, Medicine Faculty of Başkent University, Ankara, Turkey
}

\begin{abstract}
Background: This study aims to investigate the efficacy of tissue Doppler echocardiography for the diagnosis of right ventricular dysfunction and for the evaluation of the response to pulmonary valve replacement.

Methods: Between December 2008 and December 2010, a total of 15 patients ( 8 males, 7 females; mean age: $14.5 \pm 4.5$ years; range, 7 to 22 years) with pulmonary valve insufficiency in the follow-up of total correction of tetralogy of Fallot who underwent pulmonary valve replacement were included in the study. Echocardiographic imaging was performed before and one, three, and six months after replacement. Using pulse wave Doppler, early diastolic $\mathrm{E}$ and late diastolic $\mathrm{A}$ waves were measured in the flow velocity curve of tricuspid valve. Tissue Doppler measurements were made from the basal segment of right ventricular free wall and interventricular septum. S, e, and a myocardial velocities, isometric contraction time, isovolumetric relaxation time and ejection time were measured. Myocardial performance index was calculated for each patient.
\end{abstract}

Results: In pre-pulmonary valve replacement phase, s, e, a velocities and ejection time were lower in the interventricular septum compared to the basal segment of right ventricular free wall, while isometric contraction time, isovolumetric relaxation time and myocardial performance index values were higher. In the first post-replacement month, there was a significant decrease in the $\mathrm{s}$ value of interventricular septum, compared to pre-pulmonary valve replacement period; isometric contraction time decreased and myocardial performance index increased in the first postpulmonary valve replacement month in the free wall of right ventricle, while isovolumetric relaxation time decreased in the postoperative third month, and s velocity, isometric contraction time and myocardial performance index increased in the postoperative sixth month. Pre-pulmonary valve replacement tissue Doppler values at the septum showed that myocardial systolic and diastolic dysfunction developed earlier than the basal segment of right ventricular free wall. This result showed that right ventricular recovery was not complete in the sixth post-pulmonary valve replacement month.

Conclusion: Tissue Doppler can show right ventricular dysfunction before replacement, but it may be insufficient to visualize right ventricular recovery until six months after treatment.

Keywords: Echocardiography; pulmonary valve replacement; systolic dysfunction; tetralogy of Fallot. $\ddot{o Z}$

Amaç: $\mathrm{Bu}$ çalışmada sağ ventrikül disfonksiyonunun tanısında ve pulmoner kapak replasmanına yanıtın değerlendirilmesinde doku Doppler ekokardiyografisinin etkinliği araştırıldı.

Çalışma planı: Aralık 2008 - Aralık 2010 tarihleri arasında Fallot tetralojisi nedeni ile tam düzeltme yapılmış, izleminde pulmoner kapak yetmezliği gelişmiş ve pulmoner kapak replasmanı yapılmış toplam 15 hasta ( 8 erkek, 7 kadın; ort. yaş $14.5 \pm 4.5$ yıl; dağılım, 7-22 yıl) çalışmaya alındı. Replasman öncesi ve replasmandan bir, üç ve altı ay sonra ekokardiyografik görüntüleme yapıldı. Nabız dalga Doppleri ile triküspit kapak akım velosite eğrisindeki erken diyastolik E dalgası ve geç diyastolik A dalgası ölçüldü. Doku Doppler ölçümleri, sağ ventrikülün serbest duvar bazal segmentinden ve interventriküler septumdan yapıldı. S, e ve a velositeleri ile izovolümetrik kontraksiyon zamanı, izovolümetrik relaksasyon zamanı ve ejeksiyon zamanı ölçüldü. Her hasta için miyokard performans indeksi hesaplandı.

Bulgular: Replasman öncesi sağ ventrikülün serbest duvarının bazal segmentine kıyasla interventriküler septumdan alınan s, e, a velositeleri ve ejeksiyon zamanı daha düşük iken, izovolümetrik kontraksiyon zamanı ve izovolümetrik relaksasyon zamanı ile miyokard performans indeksi daha yüksek idi. Replasman öncesi döneme kıyasla, replasman sonrası birinci ayda interventriküler septum değeri, replasman öncesine göre sağ ventrikülün serbest duvarında anlamlı olarak azalır iken, triküspid kapakta replasman sonrası birinci ayda izovolümetrik kontraksiyon zamanı düștü ve miyokard performans indeksi azaldı, üçüncü ayda izovolümetrik relaksasyon zamanı azaldı, altıncı ayda ise s velositesi, izovolümetrik kontraksiyon zamanı ve miyokard performans indeksi arttı. Septumda replasman öncesi doku Doppler değerleri, sağ ventrikülün serbest duvarına göre daha erken dönemde miyokardiyal sistolik ve diyastolik disfonksiyon geliştiğini gösterdi. Bu sonuç, replasman sonrası altıncı ayda să̆ ventrikülde yeterli düzelmenin olmadığını gösterdi.

Sonuç: Doku Doppler ile replasman öncesi sağ ventrikül fonksiyonlarındaki bozulma gösterilebilir; ancak, tedavi sonrası altıncı aya kadar sağ ventrikülde yeterli düzelmeyi göstermede yetersiz kalabilir.

Anahtar sözcükler: Ekokardiyografi; pulmoner kapak replasmanı; sistolik disfonksiyon; Fallot tetralojisi.

Received: May 17, 2017 Accepted: January 11, 2018

Correspondence: Hazım Alper Gürsu, MD. Başkent Üniversitesi Tıp Fakültesi Çocuk Sağlığı ve Hastalıkları Anabilim Dalı, Çocuk Kardiyoloji Bilim Dalı, 06790 Etimesgut, Ankara, Turkey. Tel: +90 312-20368 68 e-mail: hagursu@yahoo.com.tr after pulmonary valve replacement. Turk Gogus Kalp Dama 2018;26(3):359-364. 
Pulmonary valve insufficiency (PVI) may develop after surgical treatment of tetralogy of Fallot (TOF). Severe PVI may lead to right ventricular (RV) dysfunction. As dysfunction of RV is irreversible after a certain degree, it is important to diagnose in the earlier stages and perform pulmonary valve replacement (PVR). The time between complete correction and PVR ranges from 9.9 to 22 years in the literature. ${ }^{[1-3]}$ Cardiac magnetic resonance imaging (MRI) has been indicated as the gold standard method to measure RV dimensions, volumes and systolic function. ${ }^{[4]}$ Tissue Doppler (TD) imaging is commonly used for the evaluation of global systolic and diastolic functions of the heart in congenital heart diseases and demonstration of RV physiology. ${ }^{[5,6]}$ Tissue Doppler imaging is used, as it is difficult to examine ventricular endocardial movement and wall thickness with standard echocardiography.

In the present study, we aimed to investigate the efficacy of TD echocardiography for the diagnosis of $\mathrm{RV}$ dysfunction and for the evaluation of the response to PVR.

\section{PATIENTS AND METHODS}

A total of 15 patients ( 8 males, 7 females; mean age $14.5 \pm 4.5$ years; range, 7 to 22 years) who developed PVI after repair of TOF and had pulmonary valve replacement, were included in the study. The study was conducted prospectively between December 2008 and December 2010. Pre-replacement cardiac MRI was performed on all patients. Patients with moderate to severe PVI accompanied by the following criteria were included in the study and PVR was performed: (i) Right ventricle regurgitation fraction $\geq 25 \%$ and (ii) two or more of the following criteria: (i) RV end-diastolic volume index $\geq 160 \mathrm{~mL} / \mathrm{m}^{2}$, (ii) $\mathrm{RV}$ end-systolic volume index $\geq 70 \mathrm{~mL} / \mathrm{m}^{2}$, (iii) left ventricle end-diastolic volume index $\geq 65 \mathrm{~mL} / \mathrm{m}^{2}$, (iv) $\mathrm{RV}$ ejection fraction $\leq 45 \%$, (v) right ventricle outflow tract (RVOT) aneurysm, (vi) QRS duration $\geq 180 \mathrm{msn}$, (vii) moderate or severe tricuspid regurgitation, (viii) severe aortic regurgitation, (ix) clinical criteria: exercise intolerance, syncope, and heart failure. ${ }^{[7]}$

A written informed consent was obtained from each patient and/or each parent. The study protocol was approved by the Clinical Research Ethics Committee (Decree number: KA11/172). The study was conducted in accordance with the principles of the Declaration of Helsinki.

\section{Echocardiographic examination}

Echocardiographic examination was performed by a single researcher while the patient was lying on left decubitus position using Vivid i device (GEMS Tirat Carmel, Israel) and a $3 \mathrm{Mhz}$ transducer (Figure 1). Myocardial functions of all patients were examined by echocardiographic imaging performed before PVR, and one, three, and six months after replacement. The degree of pulmonary valve insufficiency was regarded as "mild" in the absence of significant regurgitating jet in the RV outlet or retrograde diastolic flow in pulmonary artery; as "moderate" in presence of retrograde diastolic flow in main pulmonary artery; and "severe" in presence of retrograde diastolic flow in branches of pulmonary arteries.

Using pulse wave (PW) Doppler, early diastolic E wave and late diastolic A wave were measured in the flow velocity curve of tricuspid valve. Tissue Doppler measurements were made from the free wall and basal segment of RV. S, e and a myocardial velocities, isometric contraction time (ICT), isovolumetric relaxation time (IRT) and ejection time (ET) were measured. Myocardial performance index (MPI) was calculated for each patient.

\section{Operative technique}

All patients included in this study previously underwent TOF repair including RVOT reconstruction with a transannular patch. Surgery for pulmonary valve regurgitation was conducted through a sternal reentry under cardiopulmonary bypass. A cardioplegic arrest was achieved in patients with demonstrated

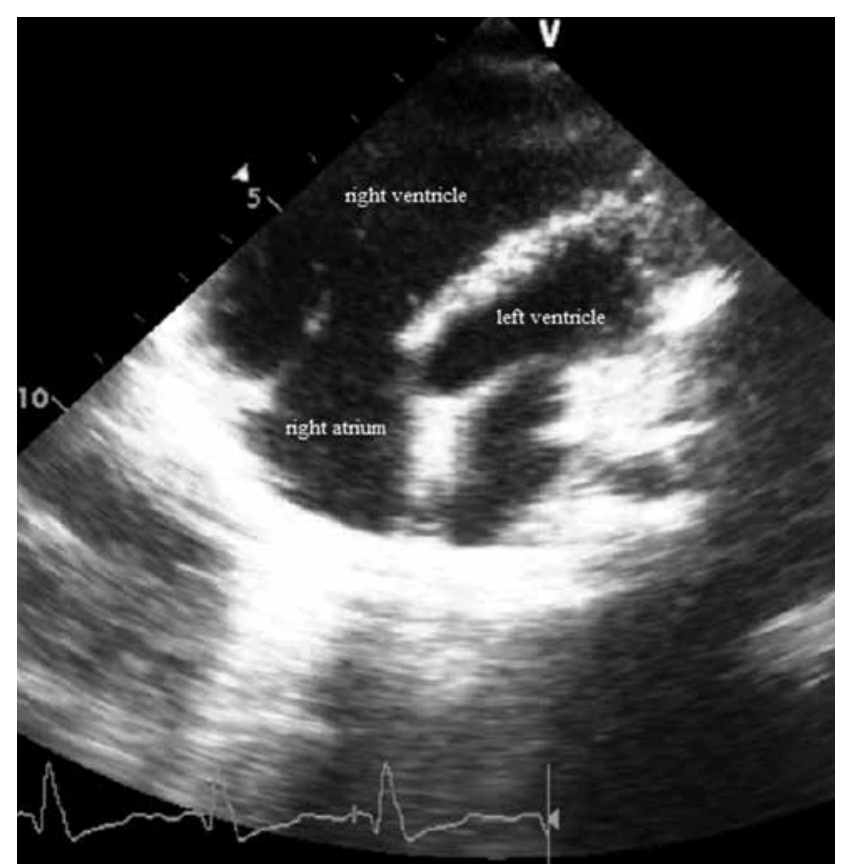

Figure 1. Two-dimensional echocardiographic view of a preoperative-pulmonary valve replacement patient. 
Table 1. Symptomatology of the patients

\begin{tabular}{lcc}
\hline Complaint & $\mathrm{n}$ & $\%$ \\
\hline Fatigue & 3 & 20 \\
Palpitation & 2 & 13.3 \\
Chest pain + fatigue & 2 & 13.3 \\
Palpitation + fatigue & 2 & 13.3 \\
Asymptomatic & 6 & 40 \\
Total & 15 & 100 \\
\hline
\end{tabular}

or suspected intracardiac residual shunt. Pulmonary valve regurgitation was handled with placement of biological valve with stents in appropriate size. In cases with aneurysmal RVOT, resection of the former transannular patch and reduction of the RV volume was done.

\section{Statistical analysis}

Statistical analysis was performed using the SPSS for Windows version 15.0 (SPSS Inc., Chicago, IL, USA).
Descriptive data were expressed in mean \pm standard deviation (SD) or number or percentage. Bi-directional variant analysis was performed in repeated measurements to investigate total correction age in time-dependent changes of the parameters and to look for the impact of time elapsed between total correction and pulmonary valve replacement. Paired t-test was used to analyze time-dependent changes in TD imaging parameters. A $p$ value of $<0.05$ was considered statistically significant.

\section{RESULTS}

Fifteen patients who suffered from severe PVI after the complete repair of TOF and went through PVR as a result of this were enrolled in the study. The mean age at the time of complete repair was $2.3 \pm 1.3$ (range, 1 to 5 ) years. The mean duration between complete repair and PVR were 11.4 years. The mean age at the time of PVR was $14.3 \pm 4.5$ (6.5 to 21.5) years. Six of the patients $(40 \%)$ were asymptomatic. The most

Table 2. Tissue Doppler values of patients

\begin{tabular}{|c|c|c|c|c|c|c|c|}
\hline & Pre-PVR & $\begin{array}{l}\text { Post-PVR } \\
\text { first month }\end{array}$ & $\begin{array}{l}\text { Post-PVR } \\
\text { third month }\end{array}$ & $\begin{array}{l}\text { Post-PVR } \\
\text { sixth month }\end{array}$ & P1 & P2 & $\mathrm{P} 3$ \\
\hline & Min-Max & Min-Max & Min-Max & Min-Max & Min-Max & Min-Max & Min-Max \\
\hline Tricuspid s (cm/s) & $3-14$ & $4-11$ & $4-12$ & $4-15$ & 0.090 & 0.167 & 0.058 \\
\hline Tricuspid e $(\mathrm{cm} / \mathrm{s})$ & $5-18$ & $5-17$ & $5-15$ & $6-17$ & 0.102 & 0.096 & 0.172 \\
\hline Tricuspid a $(\mathrm{cm} / \mathrm{s})$ & $3-9$ & $2-8$ & $4-10$ & $3-8$ & 0.120 & 0.088 & 1 \\
\hline Tricuspid ICT (ms) & $30-81$ & $41-96$ & $40-89$ & $52-89$ & 0.515 & 0.192 & 0.038 \\
\hline Tricuspid IRT (ms) & $22-73$ & $22-92$ & $36-50$ & $28-66$ & 0.575 & 0.066 & 0.477 \\
\hline Tricuspid ET (ms) & $193-451$ & $166-290$ & $233-355$ & $220-342$ & 0.007 & 0.767 & 0.314 \\
\hline Tricuspid IVA (ms) & $11-51$ & $18-52$ & $22-44$ & $22-48$ & 0.953 & 0.499 & 0.063 \\
\hline Tricuspid MPI & $220-720$ & $330-710$ & $320-480$ & $330-500$ & 0.011 & 0.025 & 0.033 \\
\hline IVS s (cm/s) & $4-10$ & $4-8$ & $4-8$ & $4-10$ & 0.047 & 0.084 & 0.890 \\
\hline IVS e $(\mathrm{cm} / \mathrm{s})$ & $6-14$ & $5-15$ & $6-11$ & $6-13$ & 0.758 & 0.091 & 0.107 \\
\hline IVS a $(\mathrm{cm} / \mathrm{s})$ & $4-8$ & $3-11$ & $4-7$ & $4-10$ & 0.787 & 0.161 & 0.672 \\
\hline IVS ICT (ms) & $55-127$ & $44-80$ & $50-94$ & $39-83$ & 0.050 & 0.374 & 0.213 \\
\hline IVS IRT (ms) & $28-133$ & $39-61$ & $29-88$ & $29-83$ & 0.507 & 0.726 & 0.779 \\
\hline IVS ET (ms) & $205-438$ & $152-321$ & $200-316$ & $221-305$ & 0.239 & 0.767 & 0.674 \\
\hline IVS IVA (ms) & $24-61$ & $22-52$ & $28-50$ & $22-51$ & 0.505 & 0.233 & 0.374 \\
\hline IVS MPI & $290-750$ & $330-750$ & $280-560$ & $330-530$ & 0.432 & 0.373 & 0.260 \\
\hline Tricuspid E & $0.44-1.18$ & $0.55-1.14$ & $0.50-0.88$ & $0.57-0.99$ & 0.583 & 0.833 & 0.812 \\
\hline Tricuspid A & $0.41-0.94$ & $0.33-1.10$ & $0.37-1.26$ & $0.33-0.87$ & 0.504 & 0.513 & 0.735 \\
\hline
\end{tabular}

Min: Minimum; Max: Maximum; Pre: Preoperative; Post: Postoperative; PVR: Pulmonary valve replacement; ICT: Isovolumetric contraction time; IRT: Isovolumetric relaxation time; ET: Ejection time; IVA: Isovolumetric acceleration time; MPI: Myocardial performance index; IVS: Interventricular septum; P1: Pre-PVR/Post-PVR first month; P2: Pre-PVR/Post-PVR third month; P3: Pre-PVR/Post-PVR sixth month. 
common complaints was fatigue (20\%), palpitation (13.3\%), and chest pain (13.3\%) (Table 1).

Despite the presence of distinct PVI in all patients, there was a difference between the severity of the disease among the patients. One patient had mild, 11 patients had severe, and three patients had moderate PVI. A total of $73.3 \%$ of the patients had severe PVI. Four of 15 patients underwent additional surgery during PVR. Two patients were treated with right pulmonary artery reconstruction, one with bifurcation plasty, and the other one with tricuspid plasty.

In addition, s, e, a, ICT, IRT, and ET were measured from the basal segment of RV free wall and IVS prior to PVR and one, three, and six months after PVR, and MPI were calculated (Table 2). In pre-PVR phase, s, e, a velocities and ET from IVS were lower than the values from the basal segment of RV free wall while ICT, IRT and MPI values were higher, indicating that systolic and diastolic dysfunction in IVS was more distinct than the free wall of RV in pre-PVR phase. In the first postreplacement month, there was a significant decrease in the $s$ values of IVS compared to pre-PVR period; ICT decreased and MPI increased in the first post-PVR month in the free wall of RV and IRT decreased in the third postoperative month, $\mathrm{s}$ velocity, ICT and MPI increased in the sixth postoperative month.

A statistically significant difference was found in terms of MPI in the basal segment of the free wall of right ventricle (RVFW) between pre-PVR phase and in the first, third, and sixth post-PVR months ( $\mathrm{p} 1=0.011, \mathrm{p} 2=0.025, \mathrm{p} 3=0.033)$. In addition, there was a statistically significant difference between pre-PVR phase and in the first post-PVR month in terms of tricuspid ET, IVS $\mathrm{s}$ and IVS ICT $(\mathrm{p}<0.05)$. According to the findings of TD, post-PVR recovery started from the basal segment of RVFW and the first response to treatment occurred in the basal segment of RVFW. It was found that the recovery of the right ventricle could be monitored with MPI.

No statistically significant difference was found between pre-PVR and post-PVR phases in terms of inflow $\mathrm{E}$ and $\mathrm{A}$ waves of trans-tricuspid Doppler $(\mathrm{p}<0.05)$.

\section{DISCUSSION}

Echocardiography and cardiac MRI are the central modalities to assess RV function and dimension in repaired TOF patients. ${ }^{[8]}$ In recent years, threedimensional echocardiography has been developed as a useful technique for quantification of ventricular volumes. ${ }^{[9]}$ Due to the complex anatomy of RV, it is very difficult to evaluate RV function with conventional echocardiography in operated TOF patients. As diastolic dysfunction develops at an earlier stage compared to systolic dysfunction in the postoperative period, TD echocardiography proves to be a very useful technique for indicating RV dysfunction. ${ }^{[10-12]}$ It is possible to obtain information directly about both the systolic and diastolic functions of both ventricles through TD imaging. ${ }^{[13-15]}$

Early diastolic e wave representing the relaxation of myocardium decreases in patients with abnormal relaxation. This decrease is one of the earliest signs of diastolic dysfunction. ${ }^{[16,17]}$ In the presence of diastolic dysfunction, E/A $<1, \mathrm{e}<7 \mathrm{~cm} / \mathrm{s}, \mathrm{E} / \mathrm{e}>15$ can be measured. In case of restrictive physiology, E increases, A decreases, E/A becomes $>2$ and IVT becomes $<70 \mathrm{msn}$.

Recent studies including this study have shown that MPI is quite effective in showing global RV function in patients with the presence of PVI after complete repair. ${ }^{[17]}$ Moreover, this index is not affected by blood pressure, tricuspid valve insufficiency, pulmonary hypertension and geometric anomalies which are more common in RV. Myocardial velocities and time intervals obtained from TD are also effective in indicating RV function together with MPI.

High MPI values indicate RV dysfunction. ${ }^{[18]}$ In significant PVI, there is an elevation in RV ET obtained with PW Doppler and decrease in MPI values, while there is an elevation in ICT and IRT calculated with PW TD, shortening in ET and elevation in MPI value. Although MPI values obtained with PW are not sufficient to show the global function of RV, Yasuoka et al. ${ }^{[19]}$ indicates that MPI obtained with PW TD perfectly reflects the RV function in patients who develop PVI in postoperative period and that, as in our study, MPI values calculated with PW TD are distinctively high in patients with complete repair. Abd El Rahman et al. ${ }^{[20]}$ investigated RV MPI with PW Doppler method in patients with the complete repair of TOF and concluded that MPI values were below normal in $76.5 \%$ of patients. ${ }^{[20]}$ The authors reported that poor RV compliance led to a decreased in IRT and, accordingly, the calculation of MPI paradoxically low. In the aforementioned study, through PW TD, there was an elevation in ICT, IRT and, also, MPI. This can be explained by the presence of RV dilatation, paradoxical septal motion, and myocardial fibrosis.

In the presence of systolic dysfunction, there is an elevation in ICT and shortening in ET. ${ }^{[19]}$ The presence 
of both systolic and diastolic dysfunction causes myocardial relaxation anomaly and the elevation of ICT. ${ }^{[19]}$ There is an elevation in ICT and IRT in TOF patients, while ET, myocardial s, e and a velocities decrease. Elevated IRT and a decrease in myocardial e velocity constitute an early sign of delayed RV relaxation; a decrease in myocardial e velocity is an early sign of restrictive RV physiology, while elevated ICT is an early sign of delayed systolic activation. There is an elevation in ICT and IRT in TOF patients, while ET, myocardial s, e and a velocities decrease. In a study, Çetin et al. ${ }^{[21]}$ showed that $\mathrm{s}$, e, and a velocities and ET obtained from the basal segment of RV in TOF patients with severe PVI were lower, compared to the healthy control group, while ICT, IRT and MPI were higher. D'Andrea et al. ${ }^{[22]}$ showed that there were distinct changes in myocardial time intervals and velocities obtained from the basal segment of RV in TOF patients characterized by a decrease in the interventricular synchronicity and delayed RV wall activation. In the study by Çetin et al. ${ }^{[21]}$ normal s was measured as $18.2 \pm 3.2 \mathrm{~cm} / \mathrm{sec}$., e as $24.6 \pm 3.3 \mathrm{~cm} / \mathrm{sec}$, a as $15.3 \pm 2.4 \mathrm{~cm} / \mathrm{sec}$, IRT as $59.3 \pm 1.4 \mathrm{msn}$ and ICT as $88.2 \pm 17.2 \mathrm{msn}$ in the basal segment of RVFW in the control group. In the study by Vögel[, ${ }^{[23]}$ normal peak systolic $\mathrm{s}$ velocity was in the range of $11.5 \pm 0.4 \mathrm{~cm} / \mathrm{sec}$, peak e velocity value in the range of $14 \pm 0.4 \mathrm{~cm} / \mathrm{sec}$ and peak a velocity value in the range of $4.5 \pm 0.4 \mathrm{~cm} / \mathrm{sec}^{[23]}$ Normal MPI value considered important in the evaluation of RV function was measured as $0.39 \pm 0.0 .^{[24]}$ In our study, peak s and e values were lower than the normal values reported by both Çetin and Vögel, a value was lower, compared to the results of Çetin and normal, compared to the results of Vögel. Consequently, pre-PVR peak s and e velocities were calculated as low in consistence with the literature, although peak a velocity was calculated to be within the lower border of normal range. In consistent with the literature, there was a decrease in s, e, and a values, while systolic and diastolic dysfunction were present in $\mathrm{RV}$, which was more evident in IVS in pre-PVR phase. It was shown that the systolic dysfunction of RV developed in the presence of a decrease in $s$ value, the delayed relaxation of RV was present in case of a decrease in e value and restrictive RV physiology was demonstrated by a decrease in a value. However, ICT, IRT values, and MPI expected to increase in patients who developed ventricular dilatation and dysfunction did not increase; on the contrary, these values were lower than the normal values reported in the literature. As specified by Abd El Rahman et al., ${ }^{[20]}$ the continuation of restrictive physiology in RV was considered to be the cause of poor RV compliance and a decrease in ICT and, consequently, paradoxically low calculation of MPI. Although there was a significant decrease in the ET in the first post-replacement month, compared to prePVR phase, there was an elevated MPI value. It was found that IRT increased in the third post-replacement month, compared to pre-PVR phase, and there was an elevation in s velocity, ICT and MPI increased in the third post-replacement month, compared to pre-PVR phase. According to these results, it was shown that systolic and diastolic dysfunction of RV myocardium were still present in the sixth post-PVR month. This result showed us that $\mathrm{RV}$ recovery was not complete in the sixth post-PVR month. A longer period of followup was necessary in the post-PVR phase to show the correction of RV functions and the recovery of RV in post-replacement period.

Furthermore, TD values were obtained from septum within the scope of our study. It was shown that $\mathrm{s}$, e, a velocities and ET obtained from IVS in prereplacement period were lower than the values from the free wall of RV while ICT, IRT and MPI values were higher. This implied that pre-PVR IVS TD values showed myocardial dysfunction in a more evident way, compared to tricuspid annulus.

Despite its contribution to the literature, our study has some limitations. First, the number of patients is rather low to obtain a significant outcome. Second, there is no control group in the study. Finally, we were unable to use more advanced echocardiographic modalities such as three-dimensional echocardiography or speckle tracking technology for the detection of RV dysfunction.

In conclusion, we used tissue Doppler imaging for early diagnosis of right ventricular dilation and dysfunction and evaluated efficiency of treatment. Based on our study results, pre-pulmonary valve replacement of the right ventricle showed both systolic and diastolic dysfunction with tissue Doppler as low peak $\mathrm{s}$ and e velocities. The most prominent location of systolic and diastolic dysfunction in pre-pulmonary valve replacement phase was interventricular septum probably accordingly on interventricular interactions. Systolic dysfunction, abnormal relaxation and restrictive physiology have been shown to develop in the right ventricle using tissue Doppler. In contrast to the literature, no increase in isometric contraction time, isovolumetric relaxation time, and myocardial performance index was attributed to continued restrictive physiology and low compliance in the right ventricle after complete repair. The continuation of systolic and diastolic dysfunction in the right ventricle 
at six months after pulmonary valve replacement showed that right ventricular recovery has not yet developed in this period. Therefore, we believe that tissue Doppler is effective in inducing pulmonary valve replacement indication and inadequate in assessing the response to the treatment. However, further large-scale, long-term studies are needed to evaluate the efficacy of these modalities in the diagnosis.

\section{Declaration of conflicting interests}

The authors declared no conflicts of interest with respect to the authorship and/or publication of this article.

\section{Funding}

The authors received no financial support for the research and/or authorship of this article.

\section{REFERENCES}

1. Knirsch W, Dodge-Khatami A, Kadner A, Kretschmar O, Steiner J, Böttler P, et al. Assessment of myocardial function in pediatric patients with operated tetralogy of Fallot: preliminary results with $2 \mathrm{D}$ strain echocardiography. Pediatr Cardiol 2008;29:718-25.

2. Kutty S, Deatsman SL, Russell D, Nugent ML, Simpson PM, Frommelt PC. Pulmonary valve replacement improves but does not normalize right ventricular mechanics in repaired congenital heart disease: a comparative assessment using velocity vector imaging. J Am Soc Echocardiogr 2008;21:1216-21.

3. Kogon B, Plattner C, Kirshbom P, Kanter K, Leong T, Lyle $\mathrm{T}$, et al. Risk factors for early pulmonary valve replacement after valve disruption in congenital pulmonary stenosis and tetralogy of Fallot. J Thorac Cardiovasc Surg 2009;138:103-8.

4. Gnanappa GK, Rashid I, Celermajer D, Ayer J, Puranik R. Reproducibility of Cardiac Magnetic Resonance Imaging (CMRI)-Derived Right Ventricular Parameters in Repaired Tetralogy of Fallot (ToF). Heart Lung Circ 2018;27:381-5.

5. Appleton CP, Hatle LK, Popp RL. Demonstration of restrictive ventricular physiology by Doppler echocardiography. J Am Coll Cardiol 1988;11:757-68.

6. Harada K, Tamura M, Toyono M, Yasuoka K. Comparison of the right ventricular Tei index by tissue Doppler imaging to that obtained by pulsed Doppler in children without heart disease. Am J Cardiol 2002;90:566-9.

7. Geva T. Indications and timing of pulmonary valve replacement after tetralogy of Fallot repair. Semin Thorac Cardiovasc Surg Pediatr Card Surg Annu 2006:11-22.

8. Larios G, Friedberg MK. Imaging in repaired tetralogy of Fallot with a focus on recent advances in echocardiography. Curr Opin Cardiol 2017;32:490-502.

9. Senthilnathan S, Dragulescu A, Mertens L. Pulmonary Regurgitation after Tetralogy of Fallot Repair: A Diagnostic and Therapeutic Challenge. J Cardiovasc Echogr 2013;23:1-9.

10. Appleton CP, Hatle LK, Popp RL. Demonstration of restrictive ventricular physiology by Doppler echocardiography. J Am Coll Cardiol 1988;11:757-68.

11. Harada K, Tamura M, Toyono M, Yasuoka K. Comparison of the right ventricular Tei index by tissue Doppler imaging to that obtained by pulsed Doppler in children without heart disease. Am J Cardiol 2002;90:566-9.

12. Sugeng L, Weinert L, Thiele K, Lang RM. Real-time threedimensional echocardiography using a novel matrix array transducer. Echocardiography 2003;20:623-35.

13. Ishii M, Eto G, Tei C, Tsutsumi T, Hashino K, Sugahara Y, et al. Quantitation of the global right ventricular function in children with normal heart and congenital heart disease: a right ventricular myocardial performance index. Pediatr Cardiol 2000;21:416-21.

14. Tei C, Dujardin KS, Hodge DO, Bailey KR, McGoon $\mathrm{MD}$, Tajik AJ, et al. Doppler echocardiographic index for assessment of global right ventricular function. J Am Soc Echocardiogr 1996;9:838-47.

15. Lyseggen E, Rabben SI, Skulstad H, Urheim S, Risoe C, Smiseth OA. Myocardial acceleration during isovolumic contraction: relationship to contractility. Circulation 2005;111:1362-9.

16. Sohn DW, Chai IH, Lee DJ, Kim HC, Kim HS, Oh BH, et al. Assessment of mitral annulus velocity by Doppler tissue imaging in the evaluation of left ventricular diastolic function. J Am Coll Cardiol 1997;30:474-80.

17. Khankirawatana B, Khankirawatana S, Peterson B, Mahrous H, Porter TR. Peak atrial systolic mitral annular velocity by Doppler tissue reliably predicts left atrial systolic function. J Am Soc Echocardiogr 2004;17:353-60.

18. Lakoumentas JA, Panou FK, Kotseroglou VK, Aggeli KI, Harbis PK. The Tei index of myocardial performance: applications in cardiology. Hellenic J Cardiol 2005;46:52-8.

19. Yasuoka K, Harada K, Toyono M, Tamura M, Yamamoto F. Tei index determined by tissue Doppler imaging in patients with pulmonary regurgitation after repair of tetralogy of Fallot. Pediatr Cardiol 2004;25:131-6.

20. Abd El Rahman MY, Abdul-Khaliq H, Vogel M, AlexiMeskischvili V, Gutberlet M, Hetzer R, et al. Value of the new Doppler-derived myocardial performance index for the evaluation of right and left ventricular function following repair of tetralogy of fallot. Pediatr Cardiol 2002;23:502-7.

21. Cetin I, Tokel K, Varan B, Orün U, Aşlamaci S. Evaluation of right ventricular function by using tissue Doppler imaging in patients after repair of tetralogy of fallot. Echocardiography 2009;26:950-7.

22. D'Andrea A, Caso P, Sarubbi B, D'Alto M, Giovanna Russo M, Scherillo M, et al. Right ventricular myocardial activation delay in adult patients with right bundle branch block late after repair of Tetralogy of Fallot. Eur J Echocardiogr 2004;5:123-31.

23. Anderson RH, Baker EJ, Penny D, Redington AN, Rigby ML, Wernovsky G, editors. Paediatric Cardiology.3rd ed. Philadelphia: Churchill Livingston, Elsevier; 2010.

24. Oh JK, Seward JB, Tajik AJ, editors. The Echo Manuel. 2nd ed. Baltimore: Lipincott, Williams \& Wilkins; 1995. 